ЛАЗАРЕВ О. В., ст. викладач, УШАКОВ М. В., ст. викладач, ЛАЗАРСВА Н. М., інженер (Український державний університет залізничного транспорту)

\title{
Підвищення безпеки руху поїздів та якості технічного обслуговування пристроїв автоматики за рахунок удосконалення організації навчання студентів
}

Показано пряму залежність безпеки руху й якості технічного обслуговування пристроїв залізничної автоматики від рівня підготовки спеціалістів у вишах. Дана оцінка впливу виховної роботи зі студентами на ставлення до навчання та отримання знань. Виділено три основні рівні позааудиторної роботи зі студентами: загальноуніверситетський, груповий та індивідуальний. Визначено та розширено коло заходів, щяо сприяють вихованню всебічно розвиненого майбутнього фахівия. Описана залежність якості підготовки фахівия від кількості задіяних напрямів навчання й виховання та комплексу заходів впливу на кожного окремого студента nід час його навчання у виші. Впровадження викладених заходів на кафедрі автоматики та комп'ютерного телекерування рухом поӥзів Украӥнського державного університету залізничного транспорту сприяє збільшенню зацікавленості студентів у здобутті освіти європейського рівня.

Ключові слова: безпека руху, якість технічного обслуговування, виховання студентів, кураторська діяльність, професійна підготовка фахівців, рівень навчання, активізація дозвілля, науково-дослідницька діяльність.

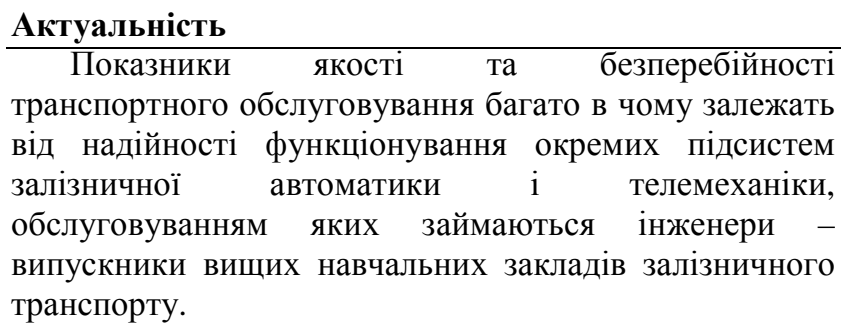

На європейських залізницях безпека має першорядне значення не тільки з точки зору втрати життя, але й з точки зору експлуатаційних витрат на ліквідацію наслідків аварій, оскільки це підриває авторитет залізниць перед вантажовідправниками [1]. Небезпека некомпетентного фахівця на залізничному транспорті не обмежується негативними наслідками його рішень [2]. Це, перш за все, небезпека для пасажирів та невчасна доставка вантажів.

Керівним документом Головного управління безпеки руху та екології [3] визначені найбільш важливі системні недоліки, до яких віднесено такі:

- $\quad$ неоперативне усунення відмов;

- неправильні дії персоналу;

- порушення технології виконання робіт, пов'язаних $з$ локалізацією та усуненням пошкоджень, технічного обслуговування та ремонту пристроїв сигналізації, централізації та блокування (СЦБ).

Це свідчить про недостатній рівень навчання й виховання інженерного персоналу.
Сучасне суспільство ставить перед випускниками вищих навчальних закладів особливі вимоги: високий рівень знань і професійної підготовки; вміння адаптуватися до ситуацій; відповідальність; ефективна взаємодія з іншими; здатність до самонавчання. У зв'язку 3 цим для підвищення ефективності та забезпечення єдності навчання і виховання студентів у вищих навчальних закладах за кожною студентською групою закріплений куратор.

\section{Постановка проблеми}

На сучасному етапі зміст діяльності куратора регламентується основними державними документами України, а саме: законом України "Про освіту", Державною національною програмою "Освіта. Україна XXI сторіччя"; "Концепцією виховання дітей та молоді у національній системі освіти"; "Національною доктриною розвитку освіти України у XXI столітті", відповідними інструктивно-методичними документами Міністерства освіти і науки України та положеннями, розробленими на рівні навчального закладу. Аналіз зазначених документів свідчить, що у своїй діяльності куратор академічної групи здійснює конкретні виховні функції: аналітичну, організаторську, комунікативну та соціальну.

() О. В. Лазарєв, М. В. Ушаков, Н. М. Лазарєва, 2018 
Теоретичний аналіз літератури, спостереження й аналіз практичної діяльності, перегляд кураторських журналів дозволяють констатувати протиріччя між багатофункціональністю виховної діяльності кураторів та відсутністю чіткого визначення основних напрямків, за якими повинна здійснюватися ця діяльність. На практиці переважна більшість кураторів обмежує коло свої обов'язків лише рамками навчальної діяльності: контроль успішності та відвідуваності.

\section{Мета}

Одним 3 факторів, що впливають на безпеку руху поїздів та якість технічного обслуговування пристроїв, $\epsilon$ рівень навченості обслуговуючого персоналу. За рахунок активізації роботи куратора зі студентами можливо виховати різнобічно розвинену особистість, яка у своїй практичній роботі буде сприяти підвищенню безпеки руху поїздів та якості транспортних послуг. Метою статті $є$ визначення напрямків та засобів удосконалення кураторської роботи у вишах.

\section{Виклад основного матеріалу}

Наявність на території України міжнародних транспортних коридорів змушує всю транспортну систему працювати на європейському рівні. Це означає, що рівень техніки, технології, організації має відповідати європейським стандартам якості та безпеки. Рівень підготовки фахівців залізничного транспорту в цих умовах не має залишатися осторонь від загальнодержавної тенденції розвитку. Неабияка роль в процесі виховання майбутніх фахівців належить кураторській діяльності.

У літературі [4-13] автори виділяють такі напрямки кураторської діяльності:

1) вивчення анкетних даних, інтересів, нахилів, побутових умов студентів;

2) надання допомоги в адаптації до нових умов навчання;

3) формування в студентській групі згуртованого колективу;

4) заохочення студентів до культурно-масової, спортивної та громадської роботи;

5) контроль поточної успішності й відвідуваності навчальних занять.

Вочевидь, наведений перелік основних напрямків виховної діяльності куратора $\epsilon$ неповним та недостатнім.

Можна виділити три основні рівні позааудиторної роботи зі студентами у вищих навчальних закладах (рис. 1).

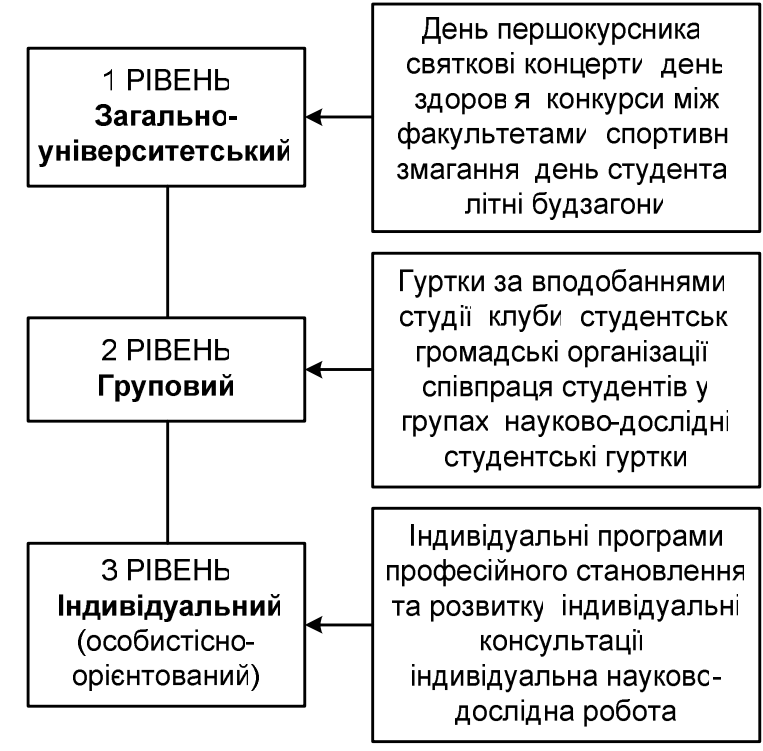

Рис. 1. Ієрархічна структура виховної роботи зі студентами

Робота куратора на кожному з цих рівнів вплине на позитивний результат виховання майбутніх фахівців.

Відомо, що безпека будь-якої складної системи визначається рівнем безпеки іiі найменш надійної ланки - людини. Згідно $з$ моделлю «людина-технікасередовище» (SHEL), що пропонується міжнародною організацією International Civil Aviation Organization, $\epsilon$ декілька чинників, які значною мірою впливають на експлуатаційну безпеку, а саме [14]:

- фізіологічні (стан здоров’я, шкідливі звички);

- психологічні;

- професійна підготовка (знання, досвід, навички управління);

- індивідуальні особливості.

Тому на допомогу кураторам пропонується комплекс заходів, що дозволять вдосконалити їх діяльність. Основні напрямки зображено на рис. 2.

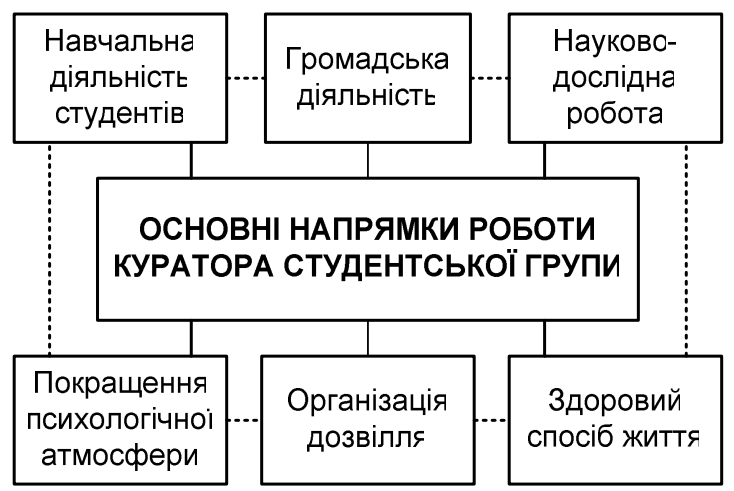

Рис. 2. Схема основних напрямків виховної діяльності куратора студентської групи 
Розглянемо діяльність куратора за кожним 3 напрямків, які $є$ складовими процесу навчання й виховання, що формує на виході фахівця

$$
\mathrm{y}=Y_{\text {нд }}+\Gamma_{д}+H_{д}+\Pi_{A}+O_{д}+3_{C ж}
$$

Удосконалення навчальної діяльності студентів. Відставання розвитку української залізниці від залізниць країн-сусідів, насамперед $\epsilon C$, $\epsilon$ очевидним. Зношеність інфраструктури й рухомого складу досягла критичного стану та потребує кардинальної модернізації. Всі ці зміни ляжуть на плечі теперішнім студентам, а незабаром - провідним фахівцям залізничного транспорту.

Навчання - діяльність, що формує майбутнього спеціаліста, його професійні, особистісні, моральні якості, активну життєву позицію. Однак, не можна розглядати навчання та позааудиторну діяльність окремо одне від одного. Крім фундаментальних наукових знань із загальноосвітніх i спеціальних предметів, навчальний процес виконує такі виховні функції:

- розвиток особистісних, вольових якостей студента;

- розвиток прагнення до самоосвіти;

- збагачення кругозору та формування світогляду людини;

- виховання почуття колективізму й співробітництва;

- формування та розвиток активної розумової діяльності.

Власний практичний досвід та аналіз літератури дозволили виділити основні виховні заходи, що сприяють підвищенню якості та ефективності навчальної діяльності студентів:

1) сприяння оволодінню системою самостійної роботи;

2) постійний контроль за відвідуванням занять та успішністю студентів;

3)використання можливості творчого підходу до вивчення предмету;

4)сприяння зміцненню віри студента в свої сили й можливості;

5)доведення до свідомості кожного, що освічена, ерудована людина має високий шанс реалізуватися як висококваліфікований фахівець.

Громадська діяльність $є$ важливим засобом, що допомагає розвинути організаторські здібності й відповідальність.

Сучасне поняття суспільної діяльності передбачає участь студентів у загальноуніверситетських заходах та отримання досвіду, необхідного для їх майбутньої професійної діяльності, а саме:

- визначення завдання;

- розрахунок терміну виконання;
- своєчасне прийняття рішення;

- узгодження з реальними умовами;

- раціональне розподілення праці;

- персональна відповідальність кожного за виконання доручень.

Основними виховними заходами куратора у цьому напрямку діяльності є:

1) інформування студентів про різноманітні громадські заходи в університеті та суспільстві;

2) заохочення студентів до громадської діяльності на власному прикладі;

3) моніторинг участі студентів у громадській діяльності.

Науково-дослідна діяльність. Інженерам XXI століття потрібно значно розширити обсяг професійного досвіду та спеціальних знань. Сучасний ринок праці висуває до випускників вишів зростаючі вимоги: володіння системними знаннями, вміння орієнтуватися в різних сферах науки, застосовувати теоретичні знання на практиці. Важливою $є$ швидка орієнтація у світі, що змінюється. Зростаючий темп морального старіння знань диктує необхідність участі студентів у дослідницькій роботі. Це дозволяе перенести акцент 3 пасивного навчання на процес активного пізнання, розвиток творчого мислення $[1,8$, 13]. Головне - це застосування знань при здійсненні конкретних проектів.

Основні виховні заходи, що можуть бути використані у цьому напрямку:

1. залучення студентів до наукової роботи у співавторстві;

2. участь у наукових студентських конференціях;

3. допомога в оформленні та виданні наукових праць студентів;

4. стимулювання до участі у олімпіадах, конкурсах.

Покращення психологічної атмосфери. Психосоціальні чинники мають значний вплив на дії людини, в тому числі створення умов для залізничних транспортних подій з різним ступенем тяжкості [12].

На жаль, вплив і значення даного фактора часто не враховується ані при вирішенні питань, пов'язаних 3 підвищенням якості навчальної діяльності студентів, ані при розселенні у гуртожитку. Тоді як саме від психологічного клімату у студентській групі залежить і успішність окремих студентів.

Тому необхідно формувати систему цінностей кожного студента, що базується на загальноєвропейській культурі. Аналіз наведених джерел [5 - 10], власний практичний досвід дозволили виділити умови, що сприяють розвитку моральних якостей студента:

1) високий рівень моральності та культури самого куратора;

2) сприйняття студентів як рівних; 
3) створення і підтримка атмосфери доброзичливості й взаємодопомоги;

4) збільшення спілкування в неформальній обстановці;

5) участь в акціях милосердя;

6) пошук індивідуального підходу до кожного студента.

Організація дозвілля передбачає зміну в бік збагачення його змісту через активізацію спортивної, культурної та розважальної діяльності [4, 10]. До основних умов збагачення дозвілля студентів можна віднести:

1) участь групи у загальноуніверситетських спортивних, культурно-масових заходах,

2) залучення до участі у гуртках за інтересами;

3) залучення студентів до мистецтва, історії, національної культури;

4) відвідання виставок, концертів;

5) організація походів на природу, у тому числі участь у акціях з очищення зелених зон від сміття.

Здоровий спосіб життя студента - це система поведінкових стереотипів, які $є$ необхідною умовою успішності у житті.

Значне збільшення обсягу предметів, що викладаються, частки самостійної роботи в навчальній діяльності вимагають від студента вміння раціонально планувати і організовувати свій час. У цьому напрямку діяльність куратора направлена на:

- допомогу в організації раціонального режиму праці і відпочинку;

- пропаганду активного способу життя;

- формування негативного ставлення до шкідливих звичок;

- застосування методів педагогічного впливу: покарання, нагородження.

Саме у студентському віці вперше відбувається відвідання нічних клубів, барів й дискотек, де $є$ небезпечні спокуси, такі як алкоголь чи наркотики. Тому куратору вкрай необхідно здійснювати виховну роботу 3 профілактики та викорінення шкідливих звичок.

Визначені, таким чином, основні напрямки роботи куратора позначимо $k_{i}\left(x_{j}\right)$. Тоді вираз (1) можна подати у вигляді $\mathrm{y}=\sum_{\mathrm{i}=1}^{\mathrm{N}}\left(k_{i}\left(x_{j}\right)\right)$.

Робота куратора по кожному 3 визначених напрямків може бути виражена у вигляді добутку його складових $k_{i}\left(x_{j}\right)=\prod_{n=1}^{m} \mu_{A_{n}}$, де $A_{n}$ - нечітка множина основних виховних заходів по кожному з напрямків роботи куратора; $\mu_{A_{n}}$ - характеристична функція, що визначає міру участі складових кожного напрямку роботи, визначених множиною $A_{n}$.
Діяльність куратора за всіма напрямами, що є складовими процесу навчання й виховання, буде мати кінцевий вигляд

$$
\mathrm{y}=\sum_{\mathrm{i}=1}^{\mathrm{N}}\left(\prod_{n=1}^{m} \mu_{A_{n}}\right)
$$

де $\prod_{n=1}^{m}$ - мультиплікація усіх заходів по основних напрямках виховної діяльності куратора 3 метою отримання всебічно розвиненого фахівця.

Результатом роботи буде максимум від декартового добутку елементів впливу на кожного окремого студента під час його навчання у виші

$$
y=f\left(A_{n}\right)=\max \left(A_{1} \times A_{2} \times \ldots \times A_{n}\right),
$$

де $A_{n}$ - кількість нечітких множин - напрямків діяльності куратора студентської групи.

3 рівняння витікає, що вихідна величина $\mathrm{y}$ i, відповідно, якість підготовки фахівця, залежить від кількості задіяних напрямів навчання й виховання та заходів впливу $k_{i}\left(x_{j}\right)$ на кожного окремого студента, а кінцевий результат підготовки фахівців буде дорівнювати $\lim _{n \rightarrow \infty} f\left(A_{n}\right)=1$.

\section{Висновки}

Розглянуті основні напрямки виховної діяльності являють собою безмежне поле діяльності куратора студентської групи. Втілення комплексу заходів за кожним 3 напрямів може надати неабияку допомогу у вихованні всебічно розвинутого i конкурентоспроможного на ринку праці майбутнього фахівця залізничного транспорту.

\section{Список використаних джерел}

1. Strategic Rail Research Agenda 2020 [Текст] // European Rail Research Advisory Council. - 2007. № $5 .-36 \mathrm{c}$.

2. Укрзализныця не смогла обеспечить должную перевозку грузов Информационное агенство «Минпром» [Электронный ресурс]. - Режим доступа: http://minprom.ua/news/224716.html Загл. с экрана. - Проверено: 01.02.2017.

3. Аналіз стану безпеки руху на залізницях України у 2014 році. [Текст] // Укрзалізниця. Головне управління безпеки руху та екології. 2015. C. 3-90.

4. Авдєєва, I. М. Інноваційні комунікативні технології в роботі куратора академгрупи [Текст]: навч. 
посібник / І. М. Авдєєва, І. М. Мельникова. - К. : ВД “Професіонал”, 2007. - 304 с.

5. Буяльська, Т. Б. Робота кураторів академічних груп у вищому навчальному закладі [Електронний ресурс] : метод. посібник / Т. Б. Буяльська, М. Д. Прищак, Л. А. Мацко. - Режим доступу : http://posibnyky.vntu. edu.ua/r_k/index.html - Назва з екрану. - Перевірено: 11.01.2017.

6. Васильєва, М. О. Роль та значення куратора в організації виховної роботи у вищій школі [Текст] / М. О. Васильєва // Проблеми інженерно-педагогічної освіти. - 2014. - № 42-43. - С. 44-47.

7. Волковницька, Т. М. Робота куратора академічної групи вищого навчального закладу як педагогічна умова професійного становлення майбутніх фахівців [Текст] / Т. М. Волковницька // Вісник Чернігівського національного педагогічного університету. Сер. : Педагогічні науки. - 2014. Вип. 115. - С. 48-50.

8. Голубова, Г.В. Педагогічні умови розвитку обдарованості студентів [Електронний ресурс] / Г. В. Голубова - - Режим доступу: http://www.rusnauka.com/

9_NND_2012/Pedagogica/2_105345.doc.htm - Назва 3 екрану. - Перевірено: 01.02.2017.

9. Державна національна програма «Освіта» (Україна XXI століття) [Текст]. - К. : Райдуга, 1994. - 61 с.

10. Литвин, I. В. Структура взаємин академічної групи як показник іiі згуртованості [Електронний ресурс] / I. В. Литвин. - Режим доступу: http://www.psyh. kiev.ua/ - Назва з екрану. - Перевірено: 01.02.2017.

11 Марті, І. В. Інноваційні комунікативні технології в роботі куратора академічної групи: методичні рекомендації [Текст] / І. В. Марті, Л.М.Барякіна, Н. В. Гришина. - Запоріжжя : ЗДІА, 2007. - 67 с.

12 Мокін, Б. І. Математичні моделі в системах управління ефективністю діяльності професорськовикладацького складу вищих навчальних закладів [Текст] : монографія / Б. І. Мокін, Ю. В. Мокіна. Вінниця: УНІВЕРСУМ-Вінниця, 2008. - 112 с.

13 Положение о кураторе учебной группы ФГОУ ВПО ПГУПС; Официальный интернет-портал Петербургского государственного университета путей сообщений [Электронный ресурс] - Режим доступа: http://www.pgups.ru/ education/students/supervision/ - Загл. с экрана. Проверено: 01.02.2017.

14 Макаренко, Л. М. Вплив людського чинника на безпеку руху залізничного транспорту [Текст]: аналітичний огляд / Л. М. Макаренко // Залізничний транспорт України. - 2010. - № 1. - С. 46-51.

А. В. Лазарев, М. В. Ушаков, Н. Н. Лазарева. Повышение безопасности движения поездов и качества технического обслуживания устройств автоматики за счет совершенствования организации обучения студентов. Показана прямая зависимость безопасности движения и качества технического обслуживания устройств железнодорожной автоматики от уровня подготовки специалистов в высших учебных заведениях. Дана оценка влияния воспитательной работы со студентами на отношение к обучению и получению знаний. Выделено три основных уровня внеаудиторной работы со студентами: общеуниверситетский, групповой и индивидуальный. Определен и расширен круг мер, которые способствуют воспитанию всесторонне развитого будущего специалиста. Описана зависимость качества подготовки специалиста от количества задействованных направлений обучения и воспитания, а также комплекса методов влияния на каждого отдельного студента во время его обучения в высшем учебном заведении. Внедрение изложенных мер на кафедре автоматики и компьютерного телеуправления движением поездов Украинского государственного университета железнодорожного транспорта способствует увеличению заинтересованности студентов в получении образования европейского уровня.

Ключевые слова: безопасность движения, качество технического обслуживания, воспитание студентов, кураторская деятельность, профессиональная подготовка специалистов, уровень обучения, активизация досуга, научно-исследовательская деятельность.

O. V. Lazariev, M. V. Ushakov, N. M. Lazarieva. Increasing the safety of train movement and the quality of automation device maintenance by the means of improvement of education and upbringing of students.

The direct dependence of traffic safety and quality of maintenance of railway automation devices from the level of training of specialists in higher educational institutions is shown. The estimation of the influence of educational work with students on the attitude to learning and obtaining knowledge is given. Three main levels of out-ofclass work with students have been singled out: general university, group and individual. The range of measures that contribute to the upbringing of a comprehensively developed future specialist has been determined and expanded. The article describes the dependence of the training quality of a specialist from the number of training and education directions involved, as well as a set of methods of influence on each individual student during his education at a higher educational institution. The introduction of the outlined measures at the Department of Automation and Computer Telecontrol of Trains of the Ukrainian State University of Railway Transport helps to 
increase the interest of students to obtaining an education of European level.

Keywords: traffic safety, quality of maintenance, education of students, curatorial activities, professional training, level of education, activation leisure, research activities.

Надійшла 25.05.2018 p.

Лазарєв О. В., ст. викладач, Український державний університет залізничного транспорту, кафедра автоматики та комп'ютерного телекерування рухом поїзів, Харків, Україна. E-mail: lazal@ukr.net, ORCID ID: 0000-0002-0186-5896.

Ушаков М. В., ст. викладач, Украӥнський державний університет залізничного транспорту, кафедра автоматики та комп'ютерного телекерування рухом поїзів, Харків, Україна. E-mail: micush@kart.edu.иа, ORCID ID: 0000-0001-6270-4212.

Лазарєва Н. М., інженер, Український державний університет залізничного транспорту, кафедра автоматики та комп'ютерного телекерування рухом поїзів, Харків, Украӥна. E-mail: laznata@ukr.net, ORCID ID: 0000-0002-2387-6334.

Lazariev Oleksii, lecturer, Department of Automatic and Computer Telemechanic of Railway Traffic Ukrainian State University of Railway Transport, Kharkiv, Ukraine. E-mail: lazal@ukr.net, ORCID ID: 0000-0002-0186-5896. Ushakov Mykhailo, lecturer, Department of Automatic and Computer Telemechanic of Railway Traffic Ukrainian State University of Railway Transport, Kharkiv, Ukraine. E-mail: micush@kart.edu.ua, ORCID ID: 0000-00016270-4212.

Lazarieva Natalia, engineer, Department of Automatic and Computer Telemechanic of Railway Traffic Ukrainian State University of Railway Transport, Kharkiv, Ukraine. E-mail: laznata@ukr.net, ORCID ID: 0000-0002-23876334. 